\title{
Effects of Neem [Azadirachta indica] Leaf and Seed Kernel Extracts on the Hairy Leaf Caterpillar- Eupterote mollifera [Bombycidae: Lepidoptera] insect Pests of Moringa tree [Moringa oleifera]
}

\author{
M. Kannan* ${ }^{1}$, M. Jamal Mohamed ${ }^{2}$ and G. Balasubramanian ${ }^{3}$ \\ ${ }^{1,3}$ PG \& Research Department of Zoology, Aringar Anna Govt Arts Collage Cheyyar- 604407 \\ ${ }^{2}$ C. Abdul Hakeem College, PG and Research Department of Zoology, Melvisharam - 632509
}

Available online at: www.isroset.org

Received: 27/Nov/2018, Accepted: 02/Dec/2018, Online: 31/Dec/2018

\begin{abstract}
Moringa Oleifera as a drumstick tree is a small fast growing evergreen or deciduous tree. It has been known to us for a very long time for its nutritional and medicinal value. This tree is susceptible to several insect pests and diseases. The common pest of Eupterote mollifera treated with neem leaf water extract and neem seed kernel extract. The fresh leaves and seeds of Azadirachta indica (Neem) were collected from the field and shade dried then powdered leaf and seed. This powder was used for the preparation of $5.0 \%$ stock solution. Thereafter, the following concentration were prepared by stock solution as $3.75 \%, 2.5 \%, 1.25 \%, 0.625 \%, 0.5 \%$, and $0.25 \%$. The present experiment was done against E. mollifera after treatment the caterpillar's activities of feeding body weight loss and gain results were observed and discussed.
\end{abstract}

Keywords: Moringa oleifera, Neem leaf, neem seed kernel, Eupterote mollifera, pest.

\section{INTRODUCTION}

Moringa oleifera as a Drumstick tree is a small, fast growing evergreen or deciduous tree that usually grows up to 10 or $12 \mathrm{~m}$ in height. It has spreading, open crown of droping, fragile branches, feathery foliage of tripinnate leaves and thick corkely whitish bark. Moringa oleifera is the most widely cultivated species of a monogeneric family. The moringaceae, that is native to the sub Himalayan tracts of India, Pakistan, Bangladesh, and Afghanistan. It is a perennial soft wood tree, with timber of low quality, which for centuries has been advocated for traditional, medicinal and industrial uses. All parts of the moringa tree are edible and have long been consumed by humans. Many uses of moringa include it as alley cropping, animal forage, bio-gas protection, domestic cleaning agent, blue dye, fencing, fertilizer, foliar nutrient, gum, honey, medicine (all parts) water purification by using seed powder, moringa trees have been used to combat malnutrition, especially among infants and nursing mothers [1]. Although moringa has been known to us for a very long time for its nutritional and medicinal value not much attention has been paid to the insect pest that affects various parts of the tree. [2,3] , have recorded major and minor insect pest that occurs on the plant damaging various parts of this tree. In its native Indian range, $M$ oleifera is susceptible to several insect pests and diseases. These include the hairy leaf - eating caterpillar, Noorda blitealis Walk and the budworm, Noorda moringae Tams, which can cause serious defoliation and flower damage and several other insect pests causing minor or only occasionally serious damage in m.oleifera $[4,5,6,7,8,9]$.

Hairy caterpillar (Eupterote mollifera) is a common pest of moringa often assuming serious proportions. The larvae defoliate the trees quickly and collect on the base of tree trunks and branches in groups. The hairs are also irritating to touch. The moth is somewhat bigger with yellowish wings having faint lines. The female lays the eggs in groups on tender parts and the larvae are brownish with thin long hairs on the body. Pupation takes place on the base of the trunk as well as in the soil. The damage by insect pests to various parts of moringa but also to enhance the production of moringa fruits, Plant protection measures are quite essential. The application of chemical pesticides will surely be hazardous and harmful, they tend to upset the natural enemy population, leave residue over treated materials proving poisonous and cause environmental pollution [10,11,12]. The essence of India's traditional wisdom with the pest repelling properties of neem rich in azadirachtin, the principle molecule in neem makes it handy and less expensive for the future formers [1]. Neem protects itself from the grip of pests with a multitude of pesticidal ingredients. Azadirachtin belong to a general class of natural products called "triterpenes", more specifically, "limonoids". About 40 compounds have been isolated from seed kernal which show biological activity against insects of these azadiractin is considered the most active. Neem products are important key insect's pests of agriculture [13]. The present experimental studies explained controlling 
measures of Neem leaf and seed kernel extracts applied against Moringa tree pest Hairy Leaf Caterpillar.

\section{MATERIALS AND METHODS}

The hairy leaf caterpillar was collected from Melseesamangalam village, Thiruvannamalai district in affected moringa trees. The observations and collection of hairy leaf caterpillar affecting parts were carried out daily morning at regular intervals four selected trees and identified later. Neem is a member of the mahogany family, Meliaceae. It is known by the botanic name Azadirachta indica A. Jus. Neem trees are attractive evergreens that can grow up to $30 \mathrm{~m}$ tall and $2.5 \mathrm{~m}$ in girth. Their spreading branches form rounded crowns as much as $20 \mathrm{~m}$ across. The leaves fall off during extreme cold and drought.

\section{Preparation of Stock Solution}

Fresh leaves and seeds of Azadirachta indica were collected from the field, washed with water to remove dusts, shade dried for 3-4 days and then powdered in the pulverize sieved using $0.01 \mathrm{~mm}$ sieve. For the purpose $25 \mathrm{gms}$ of leaf and Neeam seed KE powder was loosely bundled in a muslin cloth and soaked in $500 \mathrm{ml}$ distilled water, containing $1.0 \%$ khadhi white soap after soaking for overnight (12 hours) the material inside the bundle was kneaded and the contents was completely squeezed into water which formed 5\% stock solution ( NL WE and NSKE ). From this fresh stock solution of $5 \%$, further preparations of $3.75 \%, 2.5 \%, 1.25$ $\%, 0.625 \%, 0.5 \%$, and $0.25 \%$ concentrations were prepared by suitable dilutions with water.

\section{Experiment}

The hairy leaf caterpillar E. molllifera on moringa leaf were used and when they reached third instar, they were starved for 48 hours (over night without providing leaf for feeding). Batches of four hairy Caterpillars containing starved uniform sized larvae were separated out, weighed and provided with leaves of known surface area treated with concerned concentrations of neem leaf and seed kernel extract in water and kept in filter paper padded petridishes surface area $(10 \mathrm{~cm}$ dia- meter). Additionally treated leaves of known surface area was added to each batch when and where required up to 48 hours of the experimental periods. Then the larval batches were separated and weighed. Additional information on leaf area consumed, was also noted.

\section{RESULTS AND DISCUSSION}

In this experiment effect of neem leaf water extract and neem seed kernel extract at concentrations ranging from $0.25 \%$, to $5.0 \%$, were used to treat the leaves and the caterpillar's E. mollifera at third instar were allowed to feed for 48 hours (Table 1 and 2). The effects of treatments were compared against the control where only water was used. The results showed that NL WE at $5.0 \%$ and $3.75 \%$, did not indicate any feeding on leaves while the treatments consisting NL WE and NSKE at $0.25 \%, 0.50 \% 0.63 \%$, $1.25 \%$ and $2.50 \%$ recorded a mean feeding, ranging from $0.10 \mathrm{~cm}^{2}$ to $0.5 \mathrm{~cm}^{2}$ and $0.33 \mathrm{~cm}^{2}$ to $0.02 \mathrm{~cm}^{2}$ respectively. The control only water was used. The mean feeding was maximum, to the extent of $1.70 \mathrm{~cm}^{2}$ in NLWE and $1.68 \mathrm{~cm}^{2}$ in NSKE. The statistical analysis showed a significant difference between the feeding in control treatment and other treatments with neem leaf and neem seed extract in seven concentrations. However, all the treatments other than control did not significantly differ in effect and they were all found to be on par in efficacy.

Table 1: Effect of Neem Leaf Water Extract (NL WE) on feeding of moringa leaf by hairy caterpillar, Eupterote mollifera

\begin{tabular}{|c|c|c|c|c|c|}
\hline Treat-ments & $\begin{array}{l}\text { Neem Leaf Water Extract } \\
\text { (NL WE) in different } \\
\text { concentrations }\end{array}$ & Actual Mean & $\begin{array}{c}\text { Mean leaf } \\
\text { consumption } \\
\text { In square cm }\end{array}$ & $\begin{array}{c}\text { Decrease in } \\
\text { feeding over } \\
\text { control } \\
\text { In square cm }\end{array}$ & $\begin{array}{c}\text { decrease over } \\
\text { control } \\
(\%)\end{array}$ \\
\hline $\mathrm{T} 1$ & $5.00 \%$ & Nil & $\begin{array}{c}0.5 \\
(0.71)\end{array}$ & 1.71 & 77.38 \\
\hline $\mathrm{T} 2$ & $3.75 \%$ & Nil & $\begin{array}{c}0.5 \\
(0.71)\end{array}$ & 1.71 & 77.38 \\
\hline $\mathrm{T} 3$ & $2.50 \%$ & 0.5 & $\begin{array}{c}1.0 \\
(1.03)\end{array}$ & 1.21 & 54.75 \\
\hline $\mathrm{T} 4$ & $1.25 \%$ & 0.10 & $\begin{array}{c}0.77 \\
(0.81)\end{array}$ & 1.44 & 65.16 \\
\hline $\mathrm{T} 5$ & $0.63 \%$ & 0.19 & $\begin{array}{c}0.65 \\
(0.82)\end{array}$ & 1.56 & 70.59 \\
\hline $\mathrm{T} 6$ & $0.50 \%$ & 0.25 & $\begin{array}{c}0.7 \\
(0.85)\end{array}$ & 1.51 & 68.33 \\
\hline
\end{tabular}




\begin{tabular}{|c|c|c|c|c|c|}
\hline $\mathrm{T} 7$ & $0.25 \%$ & 0.33 & $\begin{array}{c}0.76 \\
(0.89)\end{array}$ & 1.45 & 65.61 \\
\hline $\mathrm{T} 8$ & $\begin{array}{c}\text { Control (water treatment } \\
\text { only) }\end{array}$ & 1.70 & $\begin{array}{c}2.21 \\
(1.49)\end{array}$ & - & \\
\hline
\end{tabular}

Values in parenthesis are $\sqrt{ } X+0.5$ transformed valuesIn a column mean followed by common letter(s)are not significantly different by DMRT at $\mathrm{P}=0.05$.

Table 2: Effect of Neem Seed Kernel Extract (NS KE) on feeding of moringa leaf by hairy caterpillar Eupterote mollifera

\begin{tabular}{|c|c|c|c|c|c|}
\hline Treat-ments & $\begin{array}{l}\text { Neem Seed Kernal Extract } \\
\text { (NS KE) in }\end{array}$ & Actual Mean & $\begin{array}{c}\text { Mean leaf } \\
\text { consumption } \\
\text { In square cm }\end{array}$ & $\begin{array}{c}\text { Decrease in } \\
\text { feeding over } \\
\text { control } \\
\text { In square cm }\end{array}$ & $\begin{array}{c}\text { decrease over } \\
\text { control } \\
(\%)\end{array}$ \\
\hline T1 & $5.00 \%$ & Nil & $\begin{array}{c}0.5 \\
(0.71)\end{array}$ & 1.68 & 77 \\
\hline T2 & $3.75 \%$ & Nil & $\begin{array}{c}0.5 \\
(0.71)\end{array}$ & 1.68 & 77 \\
\hline T3 & $2.50 \%$ & 0.02 & $\begin{array}{c}0.76 \\
(0.87)\end{array}$ & 1.42 & 65.13 \\
\hline T4 & $1.25 \%$ & 0.08 & $\begin{array}{c}1.0 \\
(0.98)\end{array}$ & 1.18 & 54.13 \\
\hline T5 & $0.63 \%$ & 0.17 & $\begin{array}{c}0.67 \\
(0.82)\end{array}$ & 1.51 & 69.30 \\
\hline T6 & $0.50 \%$ & 0.25 & $\begin{array}{c}0.75 \\
(0.87)\end{array}$ & 1.43 & 65.60 \\
\hline T7 & $0.25 \%$ & 0.33 & $\begin{array}{c}0.83 \\
(0.91)\end{array}$ & 1.35 & 61.93 \\
\hline T8 & \multicolumn{2}{|c|}{ Control (water treatment } \\
only)
\end{tabular}

Values in parenthesis are transformed values

In a column mean followed by common letter(s) are not significantly different by DMRT at $\mathrm{P}=0.05$.

The effect of neem leaf extract and neem seed kenarl extract on the caterpillars (E. mollifera) at third instar stage, were allowed for feeding for 48 hours with treated and untreated leaves. The larvae were also weighed both before commencing the experiment and also after completing the feeding experiment. The mean of body weight loss (-) or gain (+) in gram and data are furnished ( Table 3 and 4). In both control only water was used to treat the leaves for feeding, the mean body weight showed a gain $(+)$ of $0.02 \mathrm{gm}$, while in all other seven treatments with neem leaf water extract and neem seed kernel extract at various concentrations (5.0\% to $0.25 \%)$ the caterpillars lost (-) the body weight, which ranged from -0.03 to $-0.06 \mathrm{gm}$. and 0.04 to $-0.07 \mathrm{gms}$ respectively. The data analysis showed a significant difference between control and other treatments of other treatments of neem leaf water extract and neem seed kernel extract at different concentrations. However, the body weight loss (-) from treatments $(0.25 \%$ to $5.0 \%$ concentrations) did not show any significant difference in body weight loss (-) and they were all on par with each other.

Table 3: Effect of Neem Leaf Water Extract (NL WE) on larval body weight loss (-) or gain (+) in hairy caterpillar, Eupterote mollifera

\begin{tabular}{|l|lr|l|l|l|}
\hline $\begin{array}{l}\text { Treat- } \\
\text { ments }\end{array}$ & $\begin{array}{l}\text { Neem Leaf Water Extract } \\
\text { (NLWE) in different } \\
\text { concentrations }\end{array}$ & $\begin{array}{l}\text { Mean body } \\
\text { weight loss(-) or } \\
\text { gain (+) g. }\end{array}$ & $\begin{array}{l}\text { Increase (+) or Decrease of weight } \\
\text { Decrease(-) in weight } \\
\text { over control In g }\end{array}$ & $\begin{array}{l}\text { over control } \\
(\%)\end{array}$ \\
\hline T1 & $5.00 \%$ & & $\begin{array}{l}-0.06 \\
(0.24)\end{array}$ & -0.08 & 400 \\
\hline T2 & $3.75 \%$ & & $\begin{array}{l}-0.05 \\
(0.24)\end{array}$ & -0.07 & 350 \\
\hline
\end{tabular}




\begin{tabular}{|l|l|l|l|l|}
\hline T3 & $2.50 \%$ & $\begin{array}{l}-0.06 \\
(0.24)\end{array}$ & -0.08 & 400 \\
\hline T4 & $1.25 \%$ & $\begin{array}{l}-0.06 \\
(0.25)\end{array}$ & -0.08 & 400 \\
\hline T5 & $0.63 \%$ & $\begin{array}{l}-0.05 \\
(0.23)\end{array}$ & -0.07 & 350 \\
\hline T6 & $0.50 \%$ & $\begin{array}{l}-0.04 \\
(0.21)\end{array}$ & -0.06 & 300 \\
\hline T7 & $0.25 \%$ & $\begin{array}{l}-0.03 \\
(0.18)\end{array}$ & -0.05 & 250 \\
\hline T8 & Control (water treatment only) & $\begin{array}{l}+0.02 \\
(0.15)\end{array}$ & - & - \\
\hline
\end{tabular}

Values in parenthesis are transformed values

In a column mean followed by common letter(s) are not significantly different by DMRT at $\mathrm{P}=0.05$

Table 4: Effect of Neem Seed Kernel Extract (NS KE) on body weight loss(-)or gain (+) in hairy caterpillar Eupterote mollifera

\begin{tabular}{|c|c|c|c|c|}
\hline $\begin{array}{l}\text { Treat- } \\
\text { ments }\end{array}$ & $\begin{array}{l}\text { Neem Seed Kernal Extract (NL } \\
\text { WE) in different concentrations }\end{array}$ & $\begin{array}{l}\text { Mean body } \\
\text { weight loss }(-) \text { or } \\
\text { gain }(+) \mathrm{g} . \\
\end{array}$ & $\begin{array}{c}\text { Increase (+) or } \\
\text { Decrease }(-) \text { in weight } \\
\text { over control In } g\end{array}$ & \begin{tabular}{|c|}
$\begin{array}{c}\text { Decrease of weight } \\
\text { over control } \\
(\%)\end{array}$ \\
\end{tabular} \\
\hline $\mathrm{T} 1$ & $5.00 \%$ & $\begin{array}{l}-0.04 \\
(0.21)\end{array}$ & .06 & 300 \\
\hline $\mathrm{T} 2$ & $3.75 \%$ & $\begin{array}{l}-0.05 \\
(0.22)\end{array}$ & .07 & 350 \\
\hline $\mathrm{T} 3$ & $2.50 \%$ & $\begin{array}{l}-0.05 \\
(0.23)\end{array}$ & .07 & 350 \\
\hline $\mathrm{T} 4$ & $1.25 \%$ & $\begin{array}{l}-0.06 \\
(0.25)\end{array}$ & .08 & 400 \\
\hline T5 & $0.63 \%$ & $\begin{array}{l}-0.04 \\
(0.2)\end{array}$ & .06 & 300 \\
\hline T6 & $0.50 \%$ & $\begin{array}{l}-0.05 \\
(0.23)\end{array}$ & .07 & 350 \\
\hline $\mathrm{T} 7$ & $0.25 \%$ & $\begin{array}{l}-0.07 \\
(0.21) \\
\end{array}$ & .09 & 450 \\
\hline $\mathrm{T} 8$ & Control (water treatment only) & $\begin{array}{c}0.02 \\
(0.16)\end{array}$ & - & - \\
\hline
\end{tabular}

Values in parenthesis are transformed values

In a column mean followed by common letter(s) are not significantly different by DMRT at P=0.05.

With these details observed from various trails conducted on insects pest of crops with crude neem products, it is clear that NL WE and NS KE were also similarly effective corroborating the facts that reduction in feeding and reducing in larval body weight due to reduce feeding contributing to the effectivity of pest control. This is the case observed in present studies also when neem crude products such as NL WE and NS KE were used in different concentration ranging from $5.0 \%$ to $0.25 \%$. The caterpillars have not fed or they have fed minimally had disturbed the normal physiology and metabolism of the insect, resulting in the loss of larval body weight to varying extents. There is scope to further contact more studies involving lower concentration to study in detail the behavior of insect pest occurring on various crops. Ultimately the formers will get benefitted to use their own bio-pesticide made available from neem product, which will be more economical and profitable.

\section{CONCLUSION}

Moringa Oleifera is the worldwide cultivated species in the genus Moringa and it is fast growing, drought resistant tree. These plants are highly affected herbivores insect pest caused by several diseases. The pest control is essential for the production of moringa trees. Neem leaf and seed kernel 
water extracts are applied feeding habits were affected in this pest. Finally, the larva of hairy leaf caterpillar body weight has reduced or gained in experimental studies. Hence, active compounds are present in neem leaf and seed kernel further utilizing the control of the pest.

\section{REFERENCE}

[1] Vasantharaj David, B. and Kumaraswami, T., 1982 Elements of Economic Entomology. Pb. Popular book depot. Madras

[2] Maxwell - Lefroy, H., 1981 Indian insect life a manual of the insects of the plains

[3] Richards,O.W., Davies, and R.G., Imms., 1963. General Text Book Of Entomology.

[4] Butani,D.K.,Verma,S.,1981. Insect pest of vegetables and their control - drumsticks .pesticides 15,(10):29 - 32 .

[11]Batchelor, G.S. and K.C.Walker (1954).Health hazards involved in the use of parathion in fruit orchards of North central Washington. AMA Archives of industrial Hygiene 10: 552 529.

[13]Ramesh, C., Saxena, D., 1992. Neem a tree for solving Global problems.
[5] Kareem, A.A., Sadakathulla, S., Subramanian, T.R., 1974. Note on the severe damage of morina furits by the fly Gitona sp. (Drosophilidae: Diptera). South Indian Horticulture 22 -71.

[6] Morton, J.F., 1991. The Horesadish tree, Moringa pterygosperma (Moringaceae)- a boon to arid lands? Economic Botany 45(3)318333.

[7] Pillai, K.S. Saradamma, K., Nair, M.R., 1979. Helopeltis antonii sign, as a pest of Moringa oleifera. Current Science 49 (7) pp. 288-289.

[8] Ramachandaran, C., Peter, K.V., Gopalakrishnan, PK., 1980. Drumstick (Moringa oleifera) a multipurpose Indian vegetable. Econ. Bot. 34 (3) 276-283.

[9] Verma, A.N., Khurana, A.D., 1974. Further host records of Indarbela sp. (Lepidoptera: Matarbelidae).HarayanaAgric. Univ. J. Res. 4 (3) 253-254.

[10]Durham, W.F. and H.R.Wolfe (1962). Measurement of the exposure of workers to pesticides. Bulletin of the world Health organization

$$
\text { 26: }
$$

75-91.

[12]Lavy, T.L.et al (1980). Field Worker exposure and helicopter spray pattern of 2,4,5-T.Bulletin of Environmental Contamination and Toxicology 24: 90-96. 